\title{
Critical Success Factors in Customer Relationship Management Strategy in the Local Government Authorities in Zimbabwe
}

\author{
Douglas Chiguvi ${ }^{1}$, Ruramayi Tadu ${ }^{2} \&$ Zenzo Dube ${ }^{3}$ \\ ${ }^{1}$ Senior Lecturer, Marketing Programmes, Entrepreneurship Department, BA ISAGO University P. Bag 149, \\ Gaborone, Botswana \\ ${ }^{2}$ Vice President, Academic Affairs \& Research, BA ISAGO University, P. Bag 149, Gaborone, Botswana \\ ${ }^{3}$ Head of Entrepreneurship Department, BA ISAGO University, P. Bag 149, Gaborone, Botswana \\ Correspondence: Douglas Chiguvi, Marketing Programmes, Entrepreneurship Department, BA ISAGO \\ University P. Bag 149, Gaborone, Botswana. E-mail: dchiguvi@gmail.com
}

Received: May 18, 2019 Accepted: September 3, $2019 \quad$ Online Published: November 23, 2019

doi:10.5539/ijms.v11n4p99 URL: https://doi.org/10.5539/ijms.v11n4p99

\begin{abstract}
The aim of the study was to identify critical success factors in customer relationship management strategy success in the local government authorities in Zimbabwe. A thorough abridgment of the literature was conducted, mainly to understand the nature and structure of local government authorities in Zimbabwe as well as to identify critical success factors in CRM strategy success. A Meta-analysis methodology was employed and explanatory research approach was adopted by means of a survey strategy. 197 questionnaires have been collected from twenty-one local government authorities in Zimbabwe. The findings of the study revealed that all of the ten critical success factors are significant and positively linked to CRM strategy success. Furthermore, the statistical tests show that success and failure of CRM strategy success are highly dependent on four major critical success factors including Implementation Approach, Change Management, Metrics and Implementation Strategy. However, process design and Buy-in Approach and Adoption have low significance impact in CRM strategy success in local government authorities in Zimbabwe. The results of the data analysis led to the creation of a framework which outlines the critical success factors in CRM strategy success in local government authorities in Zimbabwe and the CRM implementation Index which need to be followed before implementing the CRM strategy. This study has clearly indicated that customer relationship management forms a powerful strategy that local government authorities should apply to manage long-term relationships with their key stakeholders.
\end{abstract}

Keywords: customer relationship management, critical success factors, local government authorities

\section{Foreword}

The local authorities in Zimbabwe are moving away from production orientation to a customer centric philosophy. The advent of technology has also triggered many of the local government authorities to adopt the CRM Strategy. Many local government authorities in Zimbabwe have partnered with Mobile Telecommunications Operators like Econet, Telecel and Net-One to use mobile phones to pay for water bills through Eco-cash, Tele-cash and One Wallet respectively. They are investing huge sums of money in the CRM, but the results on the ground are unsatisfactory as citizens are still queuing for services, and much of the work is still being done manually resulting in citizen discontentment. The authorities are still ignorant about what must be done in order to implement a successful CRM Strategy. Vazifehdust, Shahnavazi, Jourshari, and Sharifi (2012) alludes that despite the popularity of CRM systems, their success is turning out to be illusive. Arab, Selamat, Ibrahim and Zamani (2010) also point out that although the potential of the CRM is evident in government, only a few successful CRM implementation projects are known in practice. They further point out that a CRM project stands a small chance of success without considering critical success factors (CSFs). The Zimbabwe urban councils are under pressure to resolve common problems such as pot-holed roads, erratic water supplies, long queues in banking halls, burst sewer pipes, uncollected garbage, illegal dumping, clinics without drugs and non-functional street lights. All these challenges need the councils to keep a closer look at factors critical for the success of the CRM Strategy in Zimbabwe in order to provide an integrated customer service podium for improved service tracing and effective complaint resolution. The local government authorities in Zimbabwe have experienced many challenges and chief among them include lack of funding, too much central government 
interventions and so on. Competition in terms of provision of services and service delivery is also getting tougher between the local councils and the private sector in areas of waste collection and provision of ancillary services. This shows that the playing field has changed and the business relationship between the local government and stakeholders needs to be built to ensure that the two become involved in the value chain delivery system. A significant number of businesses are embracing CRM solutions to boost revenue growth, productivity, and customer satisfaction in Zimbabwe. Rababah, Mohd, and Ibrahim (2011) avowed that significant knowledge of customers enables one to better serve and keep them loyal to you forever, thus this emerges as the main Customer Relationship Management (CRM) theme. Local councils in Zimbabwe are now using mobile applications and social media platforms especially Facebook, WhatsApp to increase community involvement and service delivery. The success of the CRM Strategy critically depends on the degree to which the local government authorities follow the best critical success factors. Despite huge investment in the CRM, the local authorities are still incapable to gain the expected profits from these investments. Despite the popularity of CRM systems implementation, their success seems to be illusive (Vazifehdust, Shahnavazi, Jourshari, \& Sharifi, 2012). This study assumes that the current challenges faced by local government authorities can be alleviated if the local government authorities understand the factors that warrant the victory of CRM Strategy in the local government authorities in Zimbabwe. However, critical questions that remain are what are the factors needed for the victory of the CRM Strategy in the local government authorities in Zimbabwe. Therefore, this study sought to explore and develop a framework model of the critical success factors required for implementing a successful CRM as well as to develop a CRM implementation Index for the local government authorities in Zimbabwe.

\section{Literature Review}

\subsection{Customer Relationship Management}

Over the past decade, customer relationship management (CRM) took center stage of practice and is one of the key concepts of significance in business. The CRM concept focuses on building a long-lasting relationship for both the enterprise and clients. Although public parastatals are considered to be late followers as compared to their private sector businesses, they have recently shown substantial attentiveness in CRM. CRM help the parastatals to track and manage relationships with their citizens. CRM is a business strategy aimed to establish and develop value-creating relationships with customers (Moreno \& Melendez, 2011). Tohidi and Jabbari (2011) define CRM as a vital to realize the information infrastructures that increase the responsiveness power during compositional pressures in an organization. Arab, Selamat, Ibrahim and Zamani (2010) point out that although the potentials of CRM are evident in public sectors or government departments only few successful CRM implementation strategies are known in practice. They further point out that CRM projects would stand a small chance of success without considering Critical Success Factors. Despite its vast benefits, applying the CRM Strategy was in vain in organizations (Rigby, Reicheld, \& Schefter, 2002; King \& Burgess, 2008). Despite large investment sums by organizations in the CRM, extensive failure reports to accomplish the desired CRM results were reported (Vazifehdust et al., 2012). Finnegan and Currie (2010) also indicates that there is proof that many organizations find it difficult to operationalize the CRM Strategy.

\subsection{Critical Success Factors (CSFs)}

Numerous factors regulate the significant important ingredients for the successful implementation of CRM in an organization. Frakes (1996) described critical success factors (CSFs) as being necessary and sufficient for a victorious accomplishment; with each factor being important. The CSFs constitute the media through which management CRM is examined (Almotairi, 2009). Several researchers have endeavored to compile a comprehensive list of CSFs for the implementation of CRM Strategy (Handen, 2000; GoodHue, 2002; Finnegan, et al., 2010; Foss et al., 2008; Almotairi, 2009; Coltman et al., 2006; Vazifehdust et al., 2012). However, the lists differ due to the multi-disciplinary nature of the CRM. Vazifehdust et al. (2012) point that there is high rate of failure of CRM projects and these failures are due to lack of knowledge and in-depth understanding of the CSFs and issues needed within and across organizational setting. Therefore, this study identifies ten (10) critical success factors appropriate for the government authorities in Zimbabwe, as depicted Table 1. 
Table 1. Summary of the critical success factors

\begin{tabular}{|c|c|c|c|c|c|c|c|c|c|c|}
\hline Journal Articles & 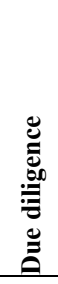 & 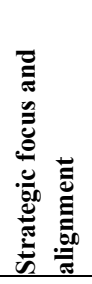 & 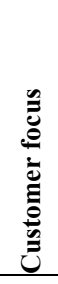 & 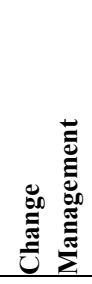 & 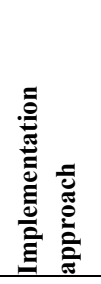 & 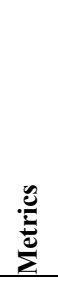 & 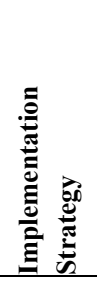 & 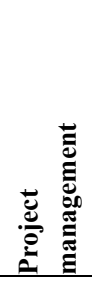 & 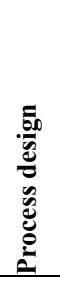 & 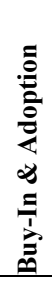 \\
\hline Avoiding critical paths of destruction (2002) & $\checkmark$ & $\checkmark$ & $\checkmark$ & & $\checkmark$ & & $\checkmark$ & & & $\checkmark$ \\
\hline Backman, S. (2009) & $\checkmark$ & $\checkmark$ & & $\checkmark$ & & & & $\checkmark$ & & \\
\hline Beasty, C. (2005) & $\checkmark$ & $\checkmark$ & $\checkmark$ & $\checkmark$ & & & $\checkmark$ & & & $\checkmark$ \\
\hline Boardman, R. (n.d.) & $\checkmark$ & $\checkmark$ & & & $\checkmark$ & $\checkmark$ & $\checkmark$ & & & $\checkmark$ \\
\hline Burns, M. (2008) & $\checkmark$ & & & & & & & & & $\checkmark$ \\
\hline CRM implementation - the right way (2009) & $\checkmark$ & $\checkmark$ & $\checkmark$ & $\checkmark$ & $\checkmark$ & $\checkmark$ & $\checkmark$ & $\checkmark$ & $\checkmark$ & \\
\hline CRM implementation (2009) & $\checkmark$ & $\checkmark$ & & $\checkmark$ & & $\checkmark$ & $\checkmark$ & & $\checkmark$ & \\
\hline Eberhardt (2001) & $\checkmark$ & $\checkmark$ & $\checkmark$ & $\checkmark$ & $\checkmark$ & $\checkmark$ & $\checkmark$ & & $\checkmark$ & $\checkmark$ \\
\hline Ganeshram and Myron (2002) & $\checkmark$ & $\checkmark$ & & & $\checkmark$ & $\checkmark$ & $\checkmark$ & $\checkmark$ & & \\
\hline Kane (2009) & $\checkmark$ & $\checkmark$ & & & $\checkmark$ & & $\checkmark$ & $\checkmark$ & $\checkmark$ & \\
\hline Lashar (2008) & $\checkmark$ & & & $\checkmark$ & $\checkmark$ & & & & & $\checkmark$ \\
\hline Lay down CRM aims to certify victory (2009) & $\checkmark$ & $\checkmark$ & $\checkmark$ & & & $\checkmark$ & & & & \\
\hline Lee (2008) & $\checkmark$ & & $\checkmark$ & & & & & & $\checkmark$ & \\
\hline Loftis, L. et al. (2004) & $\checkmark$ & $\checkmark$ & $\checkmark$ & $\checkmark$ & $\checkmark$ & & $\checkmark$ & & & \\
\hline Murtha and Foley (2001) & $\checkmark$ & $\checkmark$ & & $\checkmark$ & $\checkmark$ & $\checkmark$ & & $\checkmark$ & & \\
\hline Reel, J. S. (1999) & $\checkmark$ & & $\checkmark$ & & & & & $\checkmark$ & & $\checkmark$ \\
\hline Sethupathy, A. (2007) & $\checkmark$ & & & & $\checkmark$ & & & $\checkmark$ & & $\checkmark$ \\
\hline The upper motives- CRM success (2009) & $\checkmark$ & & $\checkmark$ & $\checkmark$ & & $\checkmark$ & $\checkmark$ & $\checkmark$ & $\checkmark$ & \\
\hline The upper motives- CRM failure (2009) & $\checkmark$ & $\checkmark$ & $\checkmark$ & $\checkmark$ & $\checkmark$ & $\checkmark$ & $\checkmark$ & & $\checkmark$ & \\
\hline Turner, K. (2007) & $\checkmark$ & $\checkmark$ & $\checkmark$ & $\checkmark$ & & $\checkmark$ & & & $\checkmark$ & \\
\hline Totals: 112 Concepts $=$ & 20 & 14 & 11 & 11 & 11 & 10 & 11 & 8 & 8 & 8 \\
\hline
\end{tabular}

Source: Chiguvi, 2017.

\subsection{Due Diligence}

All the twenty articles revealed that due diligence is a vital factor needed to be done to ensure victory of CRM Strategy. Table 1 shows that due diligence is the most common theme. This infers that the more strenuous the planning process proceeding to the project beginning is, the greater the possibility of victory. This means that rigorous planning must be done in advance prior to implementing the CRM Strategy successfully in local government authorities in Zimbabwe. Turner (2007) also confirms that due diligence is positively linked to the success of the CRM. This means that the local government authorities who want to recognize the success of the CRM Strategy should exercise due diligence prior to implementing the CRM Strategy. Boardman (2005) mentioned that enterprise CRM software is costly and therefore, due diligence is crucial prior to implementing the CRM Strategy.

\subsection{Strategy Focus and Alignment}

Strategy focus and alignment is needed to ensure successful CRM Strategy in the local government authorities. This suggests that council strategies must be aligned in the CRM Strategy and there is need of a linkage in order to detect and share finest CRM norms and standards among council personnel and other stakeholders. Turner (2007) also argued that if the strategy is not aligned, it results to disparity which will lessen the local government authority's ability to accomplish its ends. Beasty (2005) also confirmed that strategy focus is equally important in CRM Strategy.

\subsection{Customer Focus}

Table 1 above clearly indicates that customer focus is factor that needs to be considered in order to warrant the achievement of the CRM Strategy. This implies that local government authorities need to be well-versed about the facilities, products and other amenities in councils. Customer complaints must be gathered and analyzed so as to increase the realization of the CRM Strategy. Lee (2008) mentions that businesses must pay attention to the customer and priotize customer goals at the expense of their own interests. This assertion was also sustained by Reel (2009) who posits that some portions of the CRM Strategy planning stages should embrace either asking or involve the clients. This demonstrates that the local government authorities who want to achieve the success of the 
CRM Strategy should be customer centric in order to yield customer value and satisfaction. They need to understand the customer requirements and build CRM systems and strategies that create total customer value in order to achieve CRM Strategy success. This means that failure to do that will result to CRM Strategy failure in local government authorities.

\subsection{Change Management}

Table 1 also indicates that change management is a major critical success factor in CRM and this means that change management support CRM Strategy success effectively. This was also corroborated by Mohebbi, Shah Hoseini, and Esfidani (2012), and also confirmed by Jutla et al. (2005), Eid (2007), Hsin (2007), Mendoza et al. (2007) and Almotairi (2009) who all ratify that change management is linked to the victory of the CRM Strategy. This means that the local government authorities must take into account and consider change before putting in place CRM Strategy. Local government authorities need to provide innovative apparatuses and train the workers appropriately in order to deliver excellent services to the citizens.

\subsection{Implementation Approach}

Literature supports that implementation approach support CRM Strategy success effectively. This was echoed by Boardman's (2005) who mentions that the final success of the CRM Strategy is steered by change management strategies and must be implemented in phases. This allows local authorities to measure performance in phases. This factor was also backed by Lashar (2008) and Peppers and Rogers (2002) who have the view that the CRM Strategy needs to be implemented in phases. It is also important to ensure that adequate resources are put in place during the execution of the CRM Strategy.

\subsection{Metrics}

Metrics is another factor that needs to be considered when implementing CRM Strategy. It is the major factor towards the victory of the CRM Strategy. This implies that key performance indicators (KPI's) are important for the achievement of the CRM Strategy in the local government authorities among other measurement items tested. This factor was supported by Ganeshram and Myron (2002) who mentions that CRM Strategy fails when the firms lack knowledge on what they want to achieve. In addition, Cury and Kkolou (2004) sums it by mentioning that assessing the performance of the CRM Strategy is important in order to understand the best ways of improving it. This means that the local government authorities who want to enjoy the value of the CRM Strategy must ensure that the right metrics are available so as to promote excellent service quality delivery to the citizens.

\subsection{Implementation Strategy}

Literature review in Table 1 also shows that that implementation strategy is a success factor that needs to be considered in CRM Strategy. Eberhardt (2001) who mentions that lack of implementation strategy is the major cause of CRM Strategy failure. He went on further mentioning that most organizations often have one CRM champion thereby resulting in the CRM Strategy failure. Furthermore, Eberhardt (2001) underscores that if CRM approval is not agreed by all the facets of the organization, the CRM Strategy will not be accomplished. Boardman (2005) concludes that an organization without the right implementation strategies will fail to meet its goals. This critical success factor was also confirmed by Turner (2007) who reiterates that the implementation strategy is significant and positively linked to the success of the CRM Strategy. This means that local government authorities must integrate CRM systems across all the departments and also the stakeholders must be consulted and involved to ensure CRM Strategy success.

\subsection{Buy-In and Adoption}

Buy-in and adoption is needed to ensure a successful CRM Strategy in the local government authorities. This factor was buttressed by Boardman (2005) who notes that CRM Strategy implementation success is possible when management is energetically and dynamically involved in the CRM project. This researcher feels that buy-in and adoption from all stakeholder groups before and during the implementation of the CRM Strategy is vital to ensure its success in the local government authorities. It is therefore, important for local government authorities in Zimbabwe to mobilize all stakeholders to rally behind CRM Strategy initiatives and projects. Beasty (2005) indicates that CRM is contagious because its success in one department positively excites other departments.

\subsection{Project Management}

Sethupathy (2007) mentions that CRM projects are only effective and successful when the management identifies a good project leader or promoter to run and spearheading CRM Strategy. Sethupathy (2007) confirms that project management is positively linked to CRM Strategy success. It is therefore crucial that local government authorities should appoint CRM champion leaders and advocates to ensure CRM Strategy. Good project management 
techniques enable local government authorities to conduct feasibility study, estimate CRM resources and schedules, anticipate CRM risks as well as executing the CRM Strategy effectively.

\subsection{Process Design}

Process design is a success factor for CRM Strategy in the local government authorities. Eberhardt (2001), Lee (2008) and Turner (2007) all concurred that process design is linked to CRM Strategy. This means that the local government authorities must put in place the right process designs, in terms of CRM systems and equipment to ensure the success of the CRM Strategy.

Fourteen (14) sets of hypotheses were developed in this study:

H1: Due diligence is positively related to CRM Strategy in the local government authorities.

$\mathrm{H} 2$ : Strategy focus and alignment is positively related to CRM Strategy in the local government authorities.

H3: Customer focus is positively related to CRM Strategy in the local government authorities.

H4: Implementation approach is positively related to CRM Strategy in the local government authorities.

H5: Change management is positively related to CRM Strategy in the local government authorities.

H6: Metrics is positively related to CRM Strategy in the local government authorities.

H7: Implementation strategies are positively related to CRM Strategy in the local government authorities.

H8: Buy-in and Adoption is positively related to CRM Strategy in the local government authorities.

H9: Project Management is positively related to CRM Strategy in the local government authorities.

H10: Process Design is positively related to CRM Strategy in the local government authorities.

H11: The success of the CRM Strategy increases service quality in the local government authorities.

H12: The success of the CRM Strategy reduces cost in the local government authorities.

H13: The success of the CRM Strategy increases customer satisfaction in the local government authorities.

H14: The success of the CRM Strategy increases customer loyalty and trust in the local government authorities.

\section{Research Methodology}

The researcher used a quantitative research approach which was influenced by the realism and empiricist paradigms. Explanatory and descriptive research design was employed to determine the cause and effect of CSFs in CRM strategy success in the local government authorities in Zimbabwe. Meta-analysis methodology and existing literature review across many studies were employed, in order to ascertain the CSFs in CRM Strategy success appropriate for local government authorities in Zimbabwe. Raosoft sample size calculator was used to determine the sample size of 210 respondents out of 460 targeted respondents, at $95 \%$ confidence level and $5 \%$ margin of error. Purposive sampling was employed and this technique was chosen due to its practicality, as the researcher was not able to get access to a large mailing list. Questionnaire was employed to collect the data and the questionnaire consists of 58 items measurement scale to assess factors and situations critical to the success of the CRM Strategy in the local government authorities in Zimbabwe. Fourteen hypotheses were tested using 0.05 level of significance test and Pearson correlation analysis. Reliability analysis was done on all the multi items scales of the measurement instrument to authenticate the reliability of the measurement tool. In this study Cronbach's alpha was calculated in terms of the normal inter-correlations among the item evaluating the perception. According to Nunnally and Bernstein (1978) the accepted cut off point is 0.5 for Cronbach's Coefficient to attest that the measurement items are reliable. This assertation was also confirmed by Jaiyeoba (2013). This study considers the Cronbach's alpha of 0.50 as reliable. The study confirms that all the measurement items were above 0.50 as depicted in Table 2 and this mean the items were reliable to measure the critical success factors in CRM Strategy in the local government authorities in Zimbabwe. SPSS was employed to process quantitative data. The analyzed data was presented in form of tables and charts for easy readability and understanding of the research findings. 
Table 2. Cronbach alpha results for each CSF

\begin{tabular}{lll}
\hline Critical Success Factor & Cronbach's Alpha & No: of constructs \\
\hline Due Diligence & 0.506 & 4 \\
Strategic Focus and Alignment & 0.749 & 6 \\
Customer Focus & 0.884 & 5 \\
Change Management & 0.858 & 6 \\
Implementation Approach & 0.880 & 4 \\
Metrics & 0.825 & 4 \\
Implementation Strategy & 0.545 & 4 \\
Buy-in and Adoption & 0.541 & 4 \\
Project Management & 0.950 & 3 \\
Process Design & 0.827 & 4 \\
\hline
\end{tabular}

\section{Data Findings}

Table 3. Correlations matrix of critical success factors in CRM strategy in local government authorities

\begin{tabular}{|c|c|c|c|c|c|c|c|c|c|c|c|c|}
\hline \multicolumn{13}{|c|}{ Correlations } \\
\hline & & $\sum_{0}^{\infty}$ & 容 & 至 & 它 & 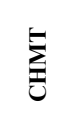 & 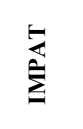 & 占 & $\underline{\hat{E}}$ & 昰 & $\sum_{i}^{E}$ & 氞 \\
\hline \multirow{5}{*}{ 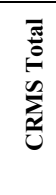 } & Pearson & 1 & $.834^{* *}$ & $.895^{* *}$ & $.940^{* *}$ & $.974^{* *}$ & $.896^{* *}$ & $.927^{* *}$ & $.916^{* *}$ & $.260^{* *}$ & $.913^{* *}$ & $.557^{* *}$ \\
\hline & Correlation & & & & & & & & & & & \\
\hline & Sig. (2-tailed) & & .000 & .000 & .000 & .000 & .000 & .000 & .000 & .005 & .000 & .000 \\
\hline & $\mathrm{N}$ & 197 & 197 & 197 & 197 & 197 & 197 & 197 & 197 & 197 & 197 & 197 \\
\hline & Pearson & $.834^{* * *}$ & 1 & $.830^{* *}$ & $.836^{* *}$ & $.839^{* *}$ & $.781^{* *}$ & $.895^{* *}$ & $.788^{* *}$ & $-.259^{* *}$ & $.821^{* *}$ & $.701^{* *}$ \\
\hline \multirow{4}{*}{ 宅 } & Correlation & & & & & & & & & & & \\
\hline & Sig. (2-tailed) & .000 & & .000 & .000 & .000 & .000 & .000 & .000 & .002 & .000 & .000 \\
\hline & $\mathrm{N}$ & 197 & 197 & 197 & 197 & 197 & 197 & 197 & 197 & 197 & 197 & 197 \\
\hline & Pearson & $.895^{* *}$ & $.830^{* *}$ & 1 & $.907^{* *}$ & $.683^{* *}$ & $.857^{* *}$ & $.751^{* *}$ & $.781^{* *}$ & $-.331^{* *}$ & $.371^{* *}$ & $.325^{* *}$ \\
\hline \multirow{4}{*}{$\frac{5}{4}$} & Correlation & & & & & & & & & & & \\
\hline & Sig. (2-tailed) & .000 & .000 & & .000 & .000 & .000 & .000 & .000 & .000 & .000 & .000 \\
\hline & $\mathrm{N}$ & 197 & 197 & 197 & 197 & 197 & 197 & 197 & 197 & 197 & 197 & 197 \\
\hline & Pearson & $.940^{* *}$ & $.836^{* *}$ & $.907^{* *}$ & 1 & $.792^{* *}$ & $.862^{* *}$ & $.829^{* *}$ & $.903^{* *}$ & $-.378^{* *}$ & $.644^{* *}$ & $.519^{* *}$ \\
\hline \multirow{4}{*}{$\sqrt{0}$} & Correlation & & & & & & & & & & & \\
\hline & Sig. (2-tailed) & .000 & .000 & .000 & & .000 & .000 & .000 & .000 & .000 & .000 & .000 \\
\hline & $\mathrm{N}$ & 197 & 197 & 197 & 197 & 197 & 197 & 197 & 197 & 197 & 197 & 197 \\
\hline & Pearson & $.974^{* *}$ & $.839^{* *}$ & $.683^{* *}$ & $.792^{* *}$ & 1 & $.725^{* *}$ & $.875^{* *}$ & $.882^{* *}$ & -.093 & $.837^{* *}$ & $.521^{* *}$ \\
\hline \multirow{4}{*}{ 点 } & Correlation & & & & & & & & & & & \\
\hline & Sig. (2-tailed) & .000 & .000 & .000 & .000 & & .000 & .000 & .000 & .194 & .000 & .000 \\
\hline & $\mathrm{N}$ & 197 & 197 & 197 & 197 & 197 & 197 & 197 & 197 & 197 & 197 & 197 \\
\hline & Pearson & $.896^{* * *}$ & $.781^{* *}$ & $.857^{* *}$ & $.862^{* *}$ & $.725^{* *}$ & 1 & $.847^{* *}$ & $.685^{* *}$ & $-.427^{* *}$ & $.463^{* *}$ & $.239^{* *}$ \\
\hline \multirow{4}{*}{ 氜 } & Correlation & & & & & & & & & & & \\
\hline & Sig. (2-tailed) & .000 & .000 & .000 & .000 & .000 & & .000 & .000 & .000 & .000 & .002 \\
\hline & $\mathrm{N}$ & 197 & 197 & 197 & 197 & 197 & 197 & 197 & 197 & 197 & 1 & 197 \\
\hline & Pearson & $.927^{* * *}$ & $.895^{* *}$ & $.751^{* *}$ & $.829^{* *}$ & $.875^{* *}$ & $.847^{* *}$ & 1 & $.796^{* *}$ & $-.379^{* *}$ & $.791^{* *}$ & $.736^{* *}$ \\
\hline \multirow{4}{*}{ 놀 } & Correlation & & & & & & & & & & & \\
\hline & Sig. (2-tailed) & .000 & .000 & .000 & .000 & .000 & .000 & & .000 & .000 & .000 & .000 \\
\hline & $\mathrm{N}$ & 197 & 197 & 197 & 197 & 197 & 155 & 188 & 188 & 188 & 188 & 188 \\
\hline & Pearson & $.916^{* *}$ & $.788^{* *}$ & $.781^{* *}$ & $.903^{* *}$ & $.882^{* *}$ & $.685^{* *}$ & $.796^{* *}$ & 1 & -.131 & $.767^{* *}$ & $.567^{* *}$ \\
\hline \multirow{4}{*}{$\stackrel{\Omega}{\Leftrightarrow}$} & Correlation & & & & & & & & & & & \\
\hline & Sig. (2-tailed) & .000 & .000 & .000 & .000 & .000 & .000 & .000 & & .067 & .000 & .000 \\
\hline & $\mathrm{N}$ & 197 & 146 & 197 & 197 & 197 & 164 & 188 & 197 & 197 & 197 & 197 \\
\hline & Pearson & $.260^{* *}$ & $-.259^{* *}$ & $-.331^{* *}$ & $-.378^{* *}$ & -.093 & $-.427^{* *}$ & $-.379^{* *}$ & -.131 & 1 & $-.261^{* *}$ & $-356^{* *}$ \\
\hline \multirow{3}{*}{ 富 } & Correlation & & & & & & & & & & & \\
\hline & Sig. (2-tailed) & .005 & .002 & .000 & .000 & .194 & .000 & .000 & .067 & & .000 & .000 \\
\hline & $\mathrm{N}$ & 197 & 146 & 197 & 197 & 197 & 164 & 188 & 197 & 197 & 197 & 197 \\
\hline \multirow{2}{*}{$\sum$} & Pearson & $.913^{* *}$ & $.821^{* *}$ & $.371^{* *}$ & $.644^{* *}$ & $.837^{* *}$ & $.463^{* *}$ & $.791^{* *}$ & $.767^{* *}$ & $-.261^{* *}$ & 1 & $.753^{* *}$ \\
\hline & Correlation & & & & & & & & & & & \\
\hline
\end{tabular}




\begin{tabular}{|c|c|c|c|c|c|c|c|c|c|c|c|c|}
\hline & Sig. (2-tailed) & .000 & .000 & .000 & .000 & .000 & .000 & .000 & .000 & .000 & & .000 \\
\hline & $\mathrm{N}$ & 197 & 146 & 197 & 197 & 197 & 164 & 188 & 197 & 197 & 197 & 197 \\
\hline \multirow{4}{*}{$\overline{\underline{a}}$} & Pearson & $.557^{* * *}$ & $.701^{* * *}$ & $.325^{* *}$ & $.519^{* * *}$ & $.521^{* *}$ & $.239^{* *}$ & $.736^{* *}$ & $.567^{* * *}$ & $-.356^{* *}$ & $.753^{* *}$ & 1 \\
\hline & Correlation & & & & & & & & & & & \\
\hline & Sig. (2-tailed) & .000 & .000 & .000 & .000 & .000 & .002 & .000 & .000 & .000 & .000 & \\
\hline & $\mathrm{N}$ & 197 & 146 & 197 & 197 & 197 & 164 & 188 & 197 & 197 & 197 & 197 \\
\hline \multirow{4}{*}{ 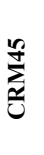 } & Pearson & $.756^{* * *}$ & $.801^{* *}$ & $.625^{* *}$ & $.549^{* *}$ & $.621^{* *}$ & $.539^{* *}$ & $.712^{* *}$ & $.627^{* * *}$ & $.456^{* *}$ & $.613^{* *}$ & 1 \\
\hline & Correlation & & & & & & & & & & & \\
\hline & Sig. (2-tailed) & .000 & .000 & .000 & .000 & .000 & .002 & .000 & .000 & .000 & .000 & \\
\hline & $\mathrm{N}$ & 197 & 146 & 197 & 197 & 197 & 164 & 188 & 197 & 197 & 197 & 197 \\
\hline \multirow{4}{*}{ 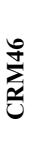 } & Pearson & $-.037^{* *}$ & $.301^{* *}$ & $.225^{* *}$ & $.419^{* *}$ & $.221^{* *}$ & $.239^{* *}$ & $.436^{* *}$ & $.527^{* *}$ & $-.656^{* *}$ & $.353^{* *}$ & 1 \\
\hline & Correlation & & & & & & & & & & & \\
\hline & Sig. (2-tailed) & .000 & .000 & .000 & .000 & .000 & .002 & .000 & .000 & .000 & .000 & \\
\hline & $\mathrm{N}$ & 197 & 146 & 197 & 197 & 197 & 164 & 188 & 197 & 197 & 197 & 197 \\
\hline \multirow{4}{*}{ 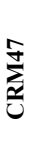 } & Pearson & $.788^{* * *}$ & $.701^{* *}$ & $.625^{* *}$ & $.519^{* * *}$ & $.721^{* *}$ & $.439^{* *}$ & $.726^{* *}$ & $.667^{* *}$ & $.556^{* *}$ & $.754^{* *}$ & 1 \\
\hline & Correlation & & & & & & & & & & & \\
\hline & Sig. (2-tailed) & .000 & .000 & .000 & .000 & .000 & .002 & .000 & .000 & .000 & .000 & \\
\hline & $\mathrm{N}$ & 197 & 146 & 197 & 197 & 197 & 164 & 188 & 197 & 197 & 197 & 197 \\
\hline \multirow{4}{*}{ 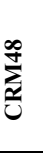 } & Pearson & $.866^{* *}$ & $.801^{* *}$ & $.725^{* *}$ & $.819^{* * *}$ & $.621^{* *}$ & $.349^{* *}$ & $.636^{* *}$ & $.567^{* * *}$ & $.756^{* *}$ & $.759^{* *}$ & 1 \\
\hline & Correlation & & & & & & & & & & & \\
\hline & Sig. (2-tailed) & .000 & .000 & .000 & .000 & .000 & .002 & .000 & .000 & .000 & .000 & \\
\hline & $\mathrm{N}$ & 197 & 146 & 197 & 197 & 197 & 164 & 188 & 197 & 197 & 197 & 197 \\
\hline
\end{tabular}

Note. ${ }^{* *}$. Significant level at the 0.05 level (2-tailed).

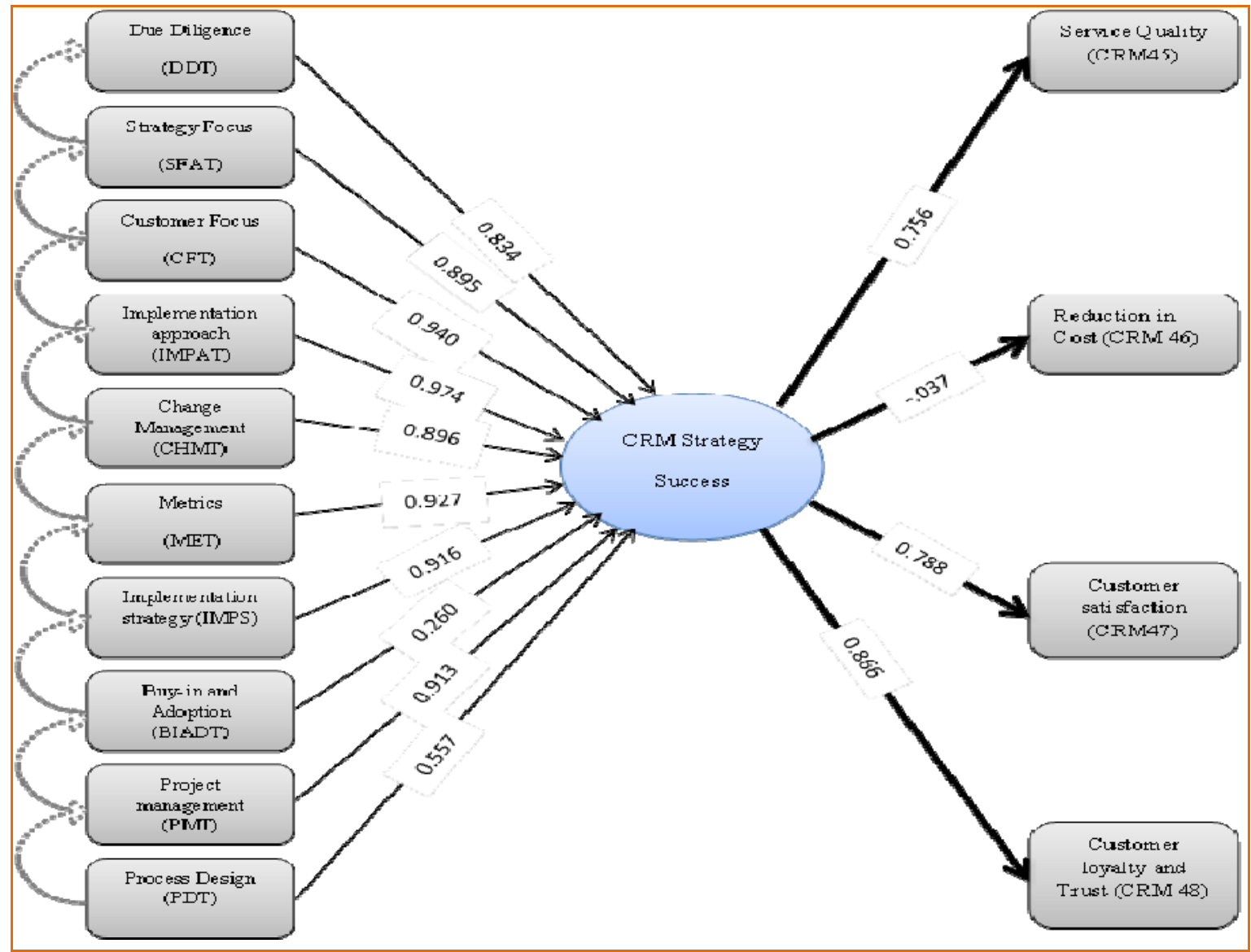

Figure 1. The final conceptual model of the critical success factors in CRM strategy success Source: Chiguvi, 2017. 


\section{CRM critical success factors in local government authorities}

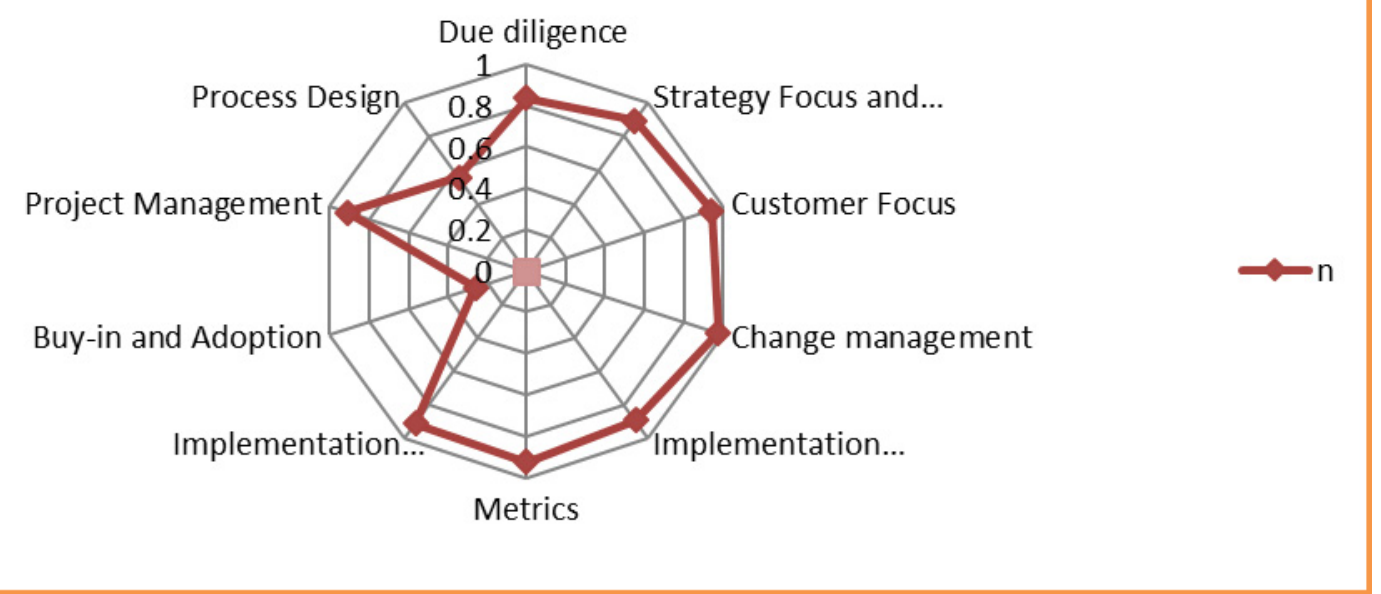

Figure 2. CRM critical success factors in local government authorities

Source: Chiguvi, 2017.

The findings of the correlation analysis as displayed in Table 3 and Figure 1 depicts that the CRM Strategy success is influenced by all the ten critical success factors of due diligence, Strategy focus and alignment, change management, metrics, implementation approach, customer focus, project management, implementation Strategy, process design and buy-in and adoption. However, the most critical success factors that explain the success of the CRM Strategy include implementation approach, change management, metrics, and implementation strategy. In a summary, the above spider diagram in Figure 2 shows that change management, implementation approach, metrics, implementation strategy, customer focus, project management and strategic focus and alignment are the most critical factors for success when implementing CRM in the local government authorities in Zimbabwe. These seven factors are directly followed by due diligence and process design. Buy-in and adoption is surprisingly the lowest rank critical success for CRM Strategy success; but still an important metric. The results in Figure 1 demonstrate the degree of influence and impact of each critical success factors (independent variables) on the success of the CRM Strategy (dependent variable). It also elucidates the degree of influence on the success of the CRM Strategy (independent variable) and on service quality, cost reduction, customer satisfaction and customer loyalty, and trust (dependent variables). At a glance Figure 1 reveals that Implementation Approach (0.974), Customer Focus (0.940), Metrics (0.927) and Implementation Strategy (0.916) have greater influence on the CRM Strategy in the local government authorities in Zimbabwe. However, the results also show that Process Design (0.557) and Buy-in and Adoption (0.260) have least influence on the success of the CRM Strategy in the local government authorities. This means that their impact in the success of the CRM Strategy is weak and below average compared to the other eight critical success factors. In a microscopic view the results show that all the ten (10) critical success factors are vital to the success of the CRM Strategy. This means that their absence will lead to CRM failure in the local government authorities in Zimbabwe.

Figure 1 also reveals the degree of influence on the success of the CRM Strategy on four CRM success factors which are service quality, reduction in cost, customer satisfaction and customer loyalty and trust. The results indicate that the success of the CRM Strategy has much impact and influence on increasing customer loyalty and trust (0.866), customer satisfaction (0.788), service quality $(0.756)$. However, the results also show that the success of the CRM Strategy is negatively linked to reduction of the cost in the local government authorities in Zimbabwe. There is no significant relationship between the success of the CRM Strategy and cost as evidenced by $(\beta=-0.037)$. The results are also confirmed by Schellong and Langenberg (2006) who posit that the common snag for the public sector is cost due to financial challenges especially at the local authorities' level. Schellong and Langenberg (2006) and Somers et al. (2001) underscore that cost is another important factor that needs to be 
deliberated before CRM Strategy is put into action. The results display that the success of the CRM Strategy involves costs in terms of human capital engagement, and IT costs among others. This might have contributed to poor cost control measures in the local government authorities in Zimbabwe. Many of the respondents are of the opinion that the success of the CRM Strategy does not result in the reduction of cost. This result might be contributed by the belief and culture of the local government authorities that CRM and marketing is expenditure. The findings of the study clearly validate that all the ten critical success factors are significantly and positively linked to the success of the CRM Strategy. This means that the local government authorities in Zimbabwe should seriously consider all the critical success factors to ensure victory of the CRM Strategy. In conclusion the researcher deduces that failure to consider them will result in CRM Strategy failure.

\section{Contribution of the Study to New Knowledge}

This study has developed a framework of vital factors of the CRM Strategy needed in the local government authorities and the study has further developed the CRM Implementation Index that the local government authorities must follow before and during the implementation of the CRM Strategy as shown in Table 4. The CRM Index measures the success of the CRM Strategy across the following ten critical success factors: Due diligence, Strategic focus and alignment, Customer focus, Change management, Implementation approach, Metrics, Implementation Strategy, Buy-in and adoption, Project management and Process design. This index has been found to be useful for executives who implement the CRM Strategy in the local government authorities. The CRM Index provides a measure for each critical success factor identified and each element is rated as high, medium and low respectively as shown in Table 4. These measures can be spot checks needed to understand the success factors required to achieve victory in the CRM programme. 
Table 4. CRM implementation index matrix

\begin{tabular}{|c|c|c|}
\hline & & Score (s) \\
\hline $\begin{array}{l}\text { Critical Success } \\
\text { Factors } \\
\text { (Pointers) }\end{array}$ & Actions & 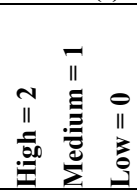 \\
\hline Due Diligence & $\begin{array}{l}\text { We do rigorous planning in advance prior to CRM Strategy implementation } \\
\text { We do Customer analysis before CRM Strategy implementation. } \\
\text { We communicate CRM goals to all stakeholders before CRM Strategy implementation. } \\
\text { We do Due diligence before CRM software and vendor selection. }\end{array}$ & \\
\hline Strategy Focus \& & Our council strategies are aligned in the CRM Strategy. & \\
\hline Alignment & $\begin{array}{l}\text { Our top managers are only involved in formulating CRM Strategy. } \\
\text { We create multidisciplinary teams when formulating CRM Strategy. } \\
\text { Network is in place to categorize and share best CRM with other stakeholders. } \\
\text { We have good partnership and harmonization in all units of the council authority. } \\
\text { Our CRM Strategy information is shared between different departments of the council. }\end{array}$ & \\
\hline Customer Focus & $\begin{array}{l}\text { Our clients are well-versed about amenities, opportunities, and other services in council. } \\
\text { We have a database to gather customers' information. } \\
\text { We have a systems and platforms to gather customer complaints and suggestions. } \\
\text { The collected information is scrutinized to solve clients' problem and improve service delivery quality. } \\
\text { We have different IT tools like blogs and Social media to deliver information and services to the clients. }\end{array}$ & \\
\hline Change & Our employees and managers are fully trained, in order to lessen resistance to change. & \\
\hline Management & $\begin{array}{l}\text { Our personnel and managers are fully trained to use CRM software. } \\
\text { We have a strong CRM oriented culture in the council. } \\
\text { Incentives and recognition are provided to encourage CRM Strategy implementation and adoption. } \\
\text { Our CRM is totally aligned with needs and expectations of different stakeholders. } \\
\text { Our CRM strategies are well planned and scheduled. }\end{array}$ & \\
\hline Implementation & Our CRM Strategy implementation is flexible. & \\
\hline Approach & $\begin{array}{l}\text { Our CRM Strategy is broken down and implemented in phases. } \\
\text { Our Council has got enough resources to implement CRM Strategy. } \\
\text { Top managers of the local councils support CRM Strategy implementation. }\end{array}$ & \\
\hline Metrics & $\begin{array}{l}\text { We have Key Performance Indicators (KPI's) to measure CRM success. } \\
\text { Our CRM processes are standard and procedures are clear. } \\
\text { Our CRM processes are continually upgraded by performance measurement tools. } \\
\text { Our CRM expectations are set for all parties involved prior to CRM Strategy implementation. }\end{array}$ & \\
\hline Implementation & Our CRM systems are integrated across all departments in the council. & \\
\hline Strategy & $\begin{array}{l}\text { All our stakeholders are consulted and involved during CRM Strategy implementation. } \\
\text { We have a CRM Strategy implementation champion in the council. } \\
\text { Our CRM Strategy rules, processes and procedures are easily available for all stakeholders. }\end{array}$ & \\
\hline Buy-in \& Adoption & $\begin{array}{l}\text { Our Mayor and Top Managers are actively involved in adopting CRM Strategy. } \\
\text { Our personnel are enthused by incentives and rewards to inspire a customer centric behaviour. } \\
\text { We provide training to employees and other CRM users prior to CRM implementation } \\
\text { We have low employee resistance to new CRM technology. }\end{array}$ & \\
\hline Project & Our CRM team has got well qualified staff. & \\
\hline Management & $\begin{array}{l}\text { Our CRM budget is adequately resourced. } \\
\text { Our CRM team is fairly represented by representatives from all departments in the council. }\end{array}$ & \\
\hline Process Design & $\begin{array}{l}\text { Our CRM processes are customer centric. } \\
\text { Our CRM processes are homogeneous. } \\
\text { Our CRM processes are user friendly. } \\
\text { Our CRM processes are constantly improved by performance measurement tools. }\end{array}$ & \\
\hline
\end{tabular}

Source: Chiguvi, 2017.

This study has therefore extended knowledge in that respect, and in the sense that it will inform the scholars dealing with the CRM topic about its impact in the African context. In addition, ten factors critical for the victory of the CRM Strategy in the local government authorities were identified. The study further revealed that a successful CRM Strategy contributes to increased customer loyalty and trust, client gratification and promotes excellent service delivery. The author believes that the study will assist the local government authorities to develop appropriate CRM strategies that will in the end be of greater value to customers. 


\section{Conclusion and Recommendations}

The study findings showed that all the identified ten critical success factors are significant and positively linked to CRM strategy success in local government authorities in Zimbabwe. Therefore, all the first ten hypotheses of the study were confirmed and accepted. The findings also confirmed that CRM strategy success have influence on the performance of local government authorities in Zimbabwe. Government support in the form of grants to the local government authorities is diminishing despite the allocations of resources to the local councils in Zimbabwe. Competition in terms of provision of services and service delivery is also getting tougher between the local councils and the private sector in the areas of waste collection and provision of ancillary services. This growing evidence is a sign that the playing field and ways of doing business in the local government authorities in Zimbabwe has changed and as such connections need to be put together with stakeholders to confirm that the stakeholders are embraced in the value chain delivery system. The local government authorities must circumvent the natural propensity to attempt and executing more work too shortly. A quick win frequently encompasses short cuts which affect the quality of work or failing to accomplish the CRM Strategy. This syndrome causes failure of the CRM Strategy. This means that the local government authorities that choose the right implementation approach must recognize the value of the CRM Strategy in their operational and strategic performance. Change management is a vital factor towards the victory of the CRM Strategy. This study found that employees in the local government authorities were production oriented. They believed in mass marketing and production. This mentality needs to be totally disremembered as it derails the success and growth of the local government authorities in Zimbabwe. Change management is needed to ensure that the CRM Strategy becomes successful. This study found that the local government authorities should have a good metrics in place in order to have got high chance of success in their CRM strategies. The researcher discovered that many the local government authorities in Zimbabwe are keeping large data but they do not have good performance audits techniques to measure the attainment of the CRM Strategy. CRM Strategy victory is decided by how it is implemented by the local government authorities. This study found that by providing a service that appeals to the Council's customers, relationship traits such as loyalty and trust, customer satisfaction and service quality are supported. Good mutual relationship enables the stakeholders to view the local government authorities as customer centric institutions.

The subsequent are the recommendations which the researcher trusts can help the local government authorities to increase the victory of the CRM Strategy as well as to successfully establish and maintain relationships with their stakeholders: The local governments authorities must exercise thorough due diligence before implementing the CRM strategies. This means that rigorous planning must be done in advance prior to implementing the CRM Strategy. Customer analysis must be done before the CRM Strategy can be implemented to ensure its success. Adequate resources must be put in place to guarantee the victory of the CRM Strategy. The local government authorities who need to enjoy the success of the CRM Strategy should also consider their strategy focus and alignment in their operational and strategic performance. The local government authorities must change their business philosophy. They need to ensure that customers are well conversant about amenities, opportunities and other services in the Councils. Information, complaints and, suggestions that come from customers must be completely gathered. The local government authorities must move away mass marketing and production to a customer-centric focus. Frequently, this factor is most overlooked by the local government authorities when implementing CRM Strategy because it took a lot of time to put into action. Reel (1999) posits that portion of the planning segment should be to consult the customers before implementing the CRM Strategy. For this method to work, the local government authorities must pay attention to the customer requirements and deliver accordingly. Local government authorities also need to provide innovative apparatuses and train the workers appropriately in order to deliver excellent services to the citizens. Apathy is one of the main anomalies encumbering the accomplishment of the CRM Strategy and with this in mind, transformation management is now mandatory to ensure the victory of the CRM Strategy as proved scientifically in this study. Good change management strategies will help to spearhead the accomplishment of CRM Strategy. Successful CRM Strategy implementation needs to be executed in phases. The stages must be well planned and scheduled to ensure smooth implementation of the CRM Strategy. They must circumvent the natural propensity to attempt and executing more work too shortly. A quick win frequently encompasses short cuts which affect the quality of work or failing to accomplish the CRM Strategy. This syndrome is the cause of CRM Strategy failure in most of the local government authorities in Zimbabwe. The Councils must try to offer excellent services in order to attract customers to pay promptly for the services rendered by the Council. The local government authorities who want to enjoy the value of the CRM Strategy must ensure that the right metrics are available so as to promote excellent service quality delivery to the citizens. The local government authorities must elucidate exactly what they need their CRM Strategy to accomplish prior to CRM implementation so that they can select the right CRM methodology accordingly. CRM 
expectations must be set for all parties involved prior to CRM Strategy implementation. This simply means that to ensure that all the CRM Strategy all facets must work together and the CRM systems must be integrated across all departments in the Council. The local government authorities must also put in place the right CRM process to speed up the entire CRM value chain system. The local government authorities must enter into strategic partnerships with the local and international investors to ensure that modern CRM systems are put in place to improve service delivery. E-commerce is a reality and the local government authorities must fully adopt social media as a strategic option for delivering quality services to citizens. The CRM processes must be customer centric and user-friendly and they need to be constantly improved from time to time. Adoption of modern technologies and continuous improvement is now a must to survive in this complex environment and to ensure the success of the CRM Strategy the local the local government authorities. The local government authorities must form partnerships with the residents and other stakeholders in order to promote mutual understanding and positive collaborations in service delivery. This infers that the local government authorities need to promote effective communication with the stakeholders and must also pay attention to clients' grievances on time. Today's citizens want better service delivery and a local government authority that is customer centric.

\section{References}

Almotairi, M. (2009, July). A framework for successful CRM implementation. In European and Mediterranean conference on information systems (pp. 1-14).

Arab, F., Selamat, H., Ibrahim, S., \& Zamani, M. (2010, October). A survey of success factors for CRM (vol. 2, pp. 20-22). In Proceedings of the World Congress on Engineering and Computer Science. https://doi.org/10.1109/ICIFE.2010.5609453

Backman, S. (2009). Avoiding technology project failure. Retrieved March 15, 2017, from http://www.idealware.org/blog/2009/01/avoiding-technology-project-failure.html

Beasty, C. (2005). 11 ways to ensure CRM success. CRM Magazine, 9, 30-33.

Boardman, R. (2005). CRM success or failure - a question for the board.

Coltman, T. R. (2006, January). Where are the benefits in CRM technology investment (Vol. 6, 111c)? In System Sciences, 2006. HICSS'06. Proceedings of the 39th Annual Hawaii International Conference on IEEE. https://doi.org/10.1109/HICSS.2006.535

CRM implementation - the right way! (2009). Retrieved March 22, 2017, from http://www.CRMinfoline.com/CRM-articles/CRM-implementation-process.htm

CRM implementation-what you should know. (2009). Retrieved March 21, 2017, from http://www.CRMinfoline.com/CRM-articles/implementing-CRM.htm

Curry, A., \& Kkolou, E. (2004). Evaluating CRM to contribute to TQM improvement-A cross-case comparison. The TQM Magazine, 16(5), 314-324. https://doi.org/10.1108/09544780410551241

Eberhardt, C. (2001). A CRM starter pack: Strategic steps to success. CRM Magazine. Retrieved May 27, 2009, from http://www.destinationCRM.com/Articles/News/Daily-News/A-CRM-Starter-

Eid, R. (2007). Towards a successful CRM implementation in banks: An integrated model. The Service Industries Journal, 27(8), 1021-1039. https://doi.org/10.1080/02642060701673703

Finnegan, D. J., \& Currie, W. L. (2010). A multi-layered approach to CRM implementation: An integration perspective. European Management Journal, 28(2), 153-167. https://doi.org/10.1016/j.emj.2009.04.010

Foss, B., Stone, M., \& Ekinci, Y. (2008). What makes for CRM system success-Or failure? The Journal of Database Marketing \& Customer Strategy Management, 15(2), 68-78. https://doi.org/10.1057/dbm.2008.5

Frakes, W., \& Terry, C. (1996). Software reuse: metrics and models. ACM Computing Surveys (CSUR), 28(2), 415-435. https://doi.org/10.1145/234528.234531

Ganeshram, R., \& Myron, D. (2002). The truth about CRM success \& failure. CRM Magazine. Retrieved February 10, 2016, from http://www.destinationCRM.com/Articles/PrintArticle.aspx?ArticleID=45491

Goodhue, D. L., Wixom, B. H., \& Watson, H. J. (2002). Realizing business benefits through CRM: hitting the right target in the right way. MIS Quarterly Executive, 1(2), 79-94.

Handen, L. (2000). Putting CRM to work: The rise of the relationship. Customer relationship management: A strategic imperative in the world of e-Business, 7-18.

Hsin, C. H. (2007). Critical factors and benefits in the implementation of customer relationship management. Total 
Quality Management, 18(5), 483-508. https://doi.org/10.1080/14783360701239941

Jaiyeoba, O. O. (2013). Revisiting the Psychometric Properties of Market Orientation Framework in an Emerging Economy: A Case-Study of Botswana's Small Service Firms. Business and Economic Research, 3(2), 236. https://doi.org/10.5296/ber.v3i2.4686

Jutla, D., Craig, J., \& Bodorik, P. (2001). January. Enabling and measuring electronic customer relationship management readiness (p. 10). In System Sciences, 2001. Proceedings of the 34th Annual Hawaii International Conference on. IEEE.

Kane, R. (2009). Straight talk: Advice from the trenches of SaaS CRM. CRM Magazine. Retrieved April 10, 2012, from http://www.CRMsoftware360.com/best-practices.htm

King, S. F., \& Burgess, T. F. (2008). Understanding success and failure in customer relationship management. Industrial Marketing Management, 37(4), 421-431. https://doi.org/10.1016/j.indmarman.2007.02.005

Lashar, J. D. (2008). Even SaaS requires the right approach. CRM Magazine. Retrieved April 10, 2012, from http://www.destinationCRM.com/Articles/PrintArticle.aspx?ArticleID=50712

Lay down CRM goals to ensure success! (2009). Retrieved April 9, 2017, from http://www.CRMinfoline.com/CRM-articles/CRM-goals.html

Lee, D. (2008). Four steps to success with CRM. CRM Today.

Loftis, L., Geiger, J. G., \& Imhoff, C. (2004). CRM success requires more than money and a mandate. Retrieved March 25, 2017, from http://searchCRM.techtarget.com/news/article/0,289142,sid11_gci969534,00.html

Mendoza, L. E., Marius, A., Pérez, M., \& Grimán, A. C. (2007). Critical success factors for a customer relationship management Strategy. Information and Software Technology, 49(8), 913-945. https://doi.org/10.1016/j.infsof.2006.10.003

Mohebbi, S., \& Li, X. (2012). Designing intelligent agents to support long-term partnership in two echelon e-Supply Networks. Expert Systems with Applications, 39(18), 13501-13508. https://doi.org/10.1016/j.eswa.2012.07.008

Moreno, A. G., \& Malendez, A. P. (2011). Analysing the impact of Knowledge Management on CRM success: The Mediating effects of organizational factors. International Journal of Information Management, 31, 437-444. https://doi.org/10.1016/j.ijinfomgt.2011.01.002

Murtha, K., \& Foley, J. (2001). Ten steps to CRM success. Information Management Magazine. Retrieved March 23, 2009, from http://www.information-anagement.com/issues/20011101/4239-1.html?zkPrintable=true

Peppers, D., \& Rogers, M. (1995). A new marketing paradigm: share of customer, not market share. Planning Review, 23(2), 14-18. https://doi.org/10.1108/eb054500

Rababah, K., Mohd, H., \& Ibrahim, H. (2011). Customer Relationship Management (CRM) Processes from Theory to Practice: The Pre-implementation Plan of CRM system. International Journal of e-Education, e-Business, e-Management and e-Learning, 1(1), 22-27. https://doi.org/10.7763/IJEEEE.2011.V1.4

Reel, J. S. (1999). Critical success factors in software projects. IEEE Software, 16(3), 18-23. https://doi.org/10.1109/52.765782

Rigby, D. K., Reichheld, F. F., \& Schefter, P. (2002). Avoid the four perils of CRM. Harvard Business Review, 80(2), 101-109.

Sethupathy, A. (2007). Predictive indicators of CRM success. Retrieved November 25, 2016, from http://nonprofitCRM.org/2007/11/10/predictive-indicators-of-CRM-success/

Somers, T. M., \& Nelson, K. (2001, January). The impact of critical success factors across the stages of enterprise resource planning implementations (p. 10). In System Sciences, 2001. Proceedings of the 34th Annual Hawaii International Conference on. IEEE.

Tohidi, H., \& Jabbari, M. M. (2011). The main requirements to implement an electronic city. Procedia Computer Science, 3, 1106-1110. https://doi.org/10.1016/j.procs.2010.12.180

Top reasons for CRM success. (2009). Retrieved March 23, 2009, from http://www.CRM-resources.net/CRM-Software-Success.php

Top reasons for failure. (2009). Retrieved March 23, 2009, from http://www.CRM-resources.net/CRM-Software-Failure.php 
Vazifehdust, H., Shahnavazi, A., Jourshari, M. R. T., \& Fataneh, S. S. (2012). Investigation critical success factors of customer relationship management implementation. World Applied Sciences Journal, 18(8), 1052-1064.

\section{Copyrights}

Copyright for this article is retained by the author, with first publication rights granted to the journal.

This is an open-access article distributed under the terms and conditions of the Creative Commons Attribution license (http://creativecommons.org/licenses/by/4.0/). 